Vegetalika. 2019. 8(4): 237-250

\title{
Hubungan Sifat Perakaran dan Ketahanan Kekeringan Lima Kultivar Kedelai (Glycine max L.)
}

\section{Relationship Between Root Characteristics and Drought Tolerance Indicators of Five Soybean Cultivars (Glycine max L.)}

\author{
Roosanna Thesa Purbowahyuani*), Dody Kastono, Didik Indradewa \\ Departemen Budidaya Pertanian, Fakultas Pertanian, Universitas Gadjah Mada \\ *) Penulis untuk koresponden Email: roosannathesa@gmail.com
}

\begin{abstract}
Drought stress is one of important limiting factors in soybean cultivation in Indonesia. The effort to reduce yield loss due to drought stress is by using soybean cultivars tolerant to drought stress. This research was conducted in plastic house located in the experimental field of Kebun Tridharma Banguntapan, Crop Science laboratory and Ecological Science laboratory of the Faculty of Agriculture, Gadjah Mada University, from April-August 2018. The aim of the research was to study the relationship between root characteristics and drought stress tolerance of several soybean cultivars. The experiment used a split plot design with three replications, two watering levels i.e. watering everyday and watering every seven days as a main plot and five cultivars i.e. Anjasmoro, Burangrang, Demas 1, Dering 1, and Devon 1 served as sub plot. The data collected was analyzed using analysis of variance (ANOVA). If there was a significant difference among treatments, then was tested using Tukey's Honest Significant Difference 95\%. The cultivar that most resistant to drought effect was Demas 1. It was concluded that soybean cultivar with larger root surface area was more resistant than cultivar that having smaller root surface areas.
\end{abstract}

Keywords: drought stress, root characteristic, drought stress tolerance, soybean

\section{INTISARI}

Cekaman kekeringan merupakan salah satu faktor pembatas dalam budidaya tanaman kedelai di Indonesia. Salah satu upaya menanggulangi penurunan hasil yang disebabkan oleh kekeringan adalah dengan menggunakan kultivar kedelai yang tahan terhadap cekaman kekeringan. Penelitian dilakukan di rumah plastik di Kebun Tridharma Banguntapan, sub Laboratorium Ilmu Tanaman dan Laboratorium Ekologi Tanaman, Fakultas Pertanian, Universitas Gadjah Mada, Yogyakarta, dari bulan April-Agustus 2018. Penelitian ini bertujuan untuk mempelajari hubungan antara sifat perakaran dan toleransi cekaman kekeringan lima kultivar kedelai. Rancangan percobaan yang digunakan adalah petak terbagi (split plot) dengan tiga ulangan. Petak utama adalah pemberian air yang terdiri dari dua aras yaitu disiram sehari sekali dan disiram tujuh hari sekali. Anak petak berupa kultivar kedelai terdiri dari kultivar Anjasmoro, Burangrang, Demas 1, Dering 1, dan Devon 1. Data yang diperoleh kemudian dianalisis dengan analisis varian (ANOVA). Apabila terdapat beda nyata antar perlakuan, dilakukan uji lanjut Beda Nyata Jujur (BNJ) Tukey dengan taraf kepercayaan 95\%. Hasil penelitian menunjukkan bahwa, kultivar 
kedelai yang paling tahan terhadap kekeringan adalah Demas 1. Kultivar kedelai yang tahan kekeringan memiliki permukaan akar yang lebih luas dibanding kultivar kedelai yang rentan kekeringan.

Kata kunci: cekaman kekeringan, sifat perakaran, indeks toleransi cekaman, kedelai

\section{PENDAHULUAN}

Kedelai merupakan tanaman pangan terpenting ketiga setelah padi dan jagung di Indonesia. Kebutuhan nasional kedelai dewasa ini telah mencapai 2,2 juta ton per tahun, sedangkan produksi dalam negeri baru mampu memenuhi kebutuhan $35-40 \%$ atau sekitar 0,8 juta ton. Tingginya kebutuhan kedelai nasional yang tidak diimbangi dengan tingginya produksi mengharuskan dilakukan impor komoditas tersebut (Badan Penelitian dan Pengembangan Pertanian, 2012).

Di Indonesia sekitar $60 \%$ kedelai ditanam di lahan sawah tadah hujan dan sawah irigasi teknis (Kasno dan Jusuf, 1994). Salah satu kendala yang dapat membatasi pertumbuhan dan produksi tanaman di lahan sawah adalah cekaman kekeringan karena ketersediaan air yang rendah. Oleh karena itu diperlukan kultivar kedelai yang berpotensi produksi dan mempunyai kemampuan adaptasi yang tinggi terhadap cekaman air. Cekaman kekeringan pada setiap tahap pertumbuhan dan perkembangan kedelai akan menimbulkan akibat yang berbeda. Menurut Mederski dan Jeffer (1973) pengaruh cekaman kekeringan terhadap hasil panen kedelai tergantung dari varietas dan tingkat cekaman kekeringan tersebut.

Pada kondisi tercekam kekeringan, kedelai tidak hanya mengalami perubahan bentuk perakaran (panjang akar, kerapatan percabangan akar, dan sudut akar) namun juga rasio tajuk akar/biomasa tanaman karena terjadinya kenaikan masa akar (Kunert et al., 2016). Pada kondisi normal, kedalaman perakaran kedelai mencapai 4,9-6,5 kaki $(149,35-198,2 \mathrm{~cm})$. Pada keadaan tercekam kekeringan akar akan mengalami penurunan rata-rata $1,27 \mathrm{~cm}$ mulai dari fase pertumbuhan stadia $\mathrm{R} 1$ (mulai muncul bunga), $5,8 \mathrm{~cm}$ per hari dari stadia R1-R3 (mulai muncul polong). Penurunan panjang akar akan terus terjadi hingga stadia R5 dan R6 (pengisian biji) (Licht et al., 2013). Penelitian ini bertujuan untuk menentukan hubungan sifat perakaran dengan ketahanan kekeringan pada lima kultivar kedelai. 


\section{BAHAN DAN METODE PENELITIAN}

Penelitian dilaksanakan di Kebun Tridharma Fakultas Pertanian, Universitas Gadjah Mada di Banguntapan, Bantul, Yogyakarta pada bulan April-Agustus 2018. Penelitian disusun menggunakan rancangan petak terbagi (split plot). Perlakuan kekeringan yang terdiri dari 2 aras yaitu cukup air (tidak tercekam) dengan disiram 1 hari sekali dan kekeringan (tercekam) dengan disiram 7 hari sekali bertindak sebagai pihak utama dan kultivar kedelai yang terdiri dari lima kultivar yaitu Anjasmoro, Burangrang, Demas 1, Dering 1, dan Devon 1 bertindak sebagai anak petak.

Penelitian dilakukan dengan penanaman benih pada polybag di lahan yang ternaungi dalam rumah plastik. Setiap unit percobaan terdiri dari 9 polibag dikali 5 perlakuan dan 6 blok sehingga total terdapat 270 polibag. Pengambilan sampel destruktif dilakukan sebanyak tiga kali, yaitu pada 4 minggu setelah tanam (MST), 8 MST dan saat panen, maing-masing sampel diambil 2 polibag/unit percobaan. Variabel yang diamati adalah kadar lengas tanah, jumlah akar, bobot kering akar, panjang akar, luas permukaan akar, diameter akar dan indeks toleransi cekaman berdasarkan berat kering tanaman. Analisis data menggunakan ANOVA dan apabila tidak terdapat interaksi antara kedua faktor dilakukan uji Honest Significant Difference Tukey dengan taraf kepercayaan $95 \%$.

Pengukuran kadar lengas dilakukan dua kali, yaitu saat sebelum penyiraman dan setelah penyiraman pada masing-masing waktu pengambilan sampel destruktif. Kadar lengas tanah diukur menggunakan rumus:

$$
\text { Kadar Lengas }(\mathrm{KL})=\frac{B B-B K}{B K} \times 100 \%
$$

Keterangan:

$\mathrm{BK}=$ bobot kering oven

$\mathrm{BB}=$ bobot basah

Indeks toleransi cekaman (ITC) berdasarkan bobot kering tanaman dihitung menggunakan persamaan Fernandez (1992):

$$
\text { ITC Berat Kering Tanaman }=\frac{Y s Y p}{P p^{2}}
$$


Keterangan:

Ys $\quad=$ Hasil biji dalam kondisi cekaman

Yp = Hasil biji dalam kondisi tidak tercekam

$\bar{Y} p^{2}=$ Rata-rata hasil biji dalam kondisi tidak tercekam

\section{HASIL DAN PEMBAHASAN}

Ketersediaan air di dalam tanah merupakan salah satu faktor pembatas utama pertumbuhan tanaman dan produksi pertanian. Ketersediaan air di lingkungan tumbuh tanaman tersebut dipengaruhi oleh lengas tanah, yaitu air yang terdapat dalam tanah terikat oleh berbagai perilaku osmosis, matrik, dan kapiler.

Tabel 1. Kadar lengas tanah sebelum dan sesudah penyiraman pada $4 \mathrm{mst}, 8 \mathrm{mst}$ dan panen

\begin{tabular}{lcccccc}
\hline & \multicolumn{5}{c}{ Kadar Lengas Tanah (\%) } \\
\cline { 2 - 7 } Perlakuan & \multicolumn{2}{c}{4 mst } & \multicolumn{2}{c}{$8 \mathrm{mst}$} & \multicolumn{2}{c}{ Panen } \\
\cline { 2 - 7 } & Sebelum & Sesudah & Sebelum & Sesudah & Sebelum & Sesudah \\
& Penyiraman & Penyiraman & Penyiraman & Penyiraman & Penyiraman & Penyiraman \\
\hline Kultivar & & & & & & \\
Anjasmoro & $16.05 \mathrm{a}$ & $26.72 \mathrm{a}$ & $14.49 \mathrm{a}$ & $19.83 \mathrm{a}$ & $16.12 \mathrm{a}$ & $21.63 \mathrm{a}$ \\
Burangrang & $18.58 \mathrm{a}$ & $29.60 \mathrm{a}$ & $10.04 \mathrm{~b}$ & $20.64 \mathrm{a}$ & $17.61 \mathrm{a}$ & $21.81 \mathrm{a}$ \\
Demas 1 & $15.29 \mathrm{a}$ & $26.66 \mathrm{a}$ & $12.29 \mathrm{ab}$ & $18.50 \mathrm{a}$ & $16.66 \mathrm{a}$ & $22.74 \mathrm{a}$ \\
Dering 1 & $16.48 \mathrm{a}$ & $27.97 \mathrm{a}$ & $10.23 \mathrm{~b}$ & $19.27 \mathrm{a}$ & $14.66 \mathrm{a}$ & $22.35 \mathrm{a}$ \\
Devon 1 & $15.23 \mathrm{a}$ & $26.43 \mathrm{a}$ & $10.22 \mathrm{~b}$ & $16.36 \mathrm{a}$ & $17.08 \mathrm{a}$ & $21.57 \mathrm{a}$ \\
\hline Penyiraman & & & & & & \\
Cukup Air & $27.83 \mathrm{p}$ & $32.44 \mathrm{p}$ & $19.08 \mathrm{p}$ & $22.16 \mathrm{p}$ & $25.94 \mathrm{p}$ & $23.55 \mathrm{p}$ \\
Kekeringan & $4.82 \mathrm{q}$ & $22.51 \mathrm{p}$ & $3.82 \mathrm{q}$ & $15.67 \mathrm{p}$ & $6.91 \mathrm{q}$ & $20.49 \mathrm{p}$ \\
\hline Interaksi & - & - & - & - & - & - \\
\hline CV (\%) & 22.72 & 15.4 & 17.94 & 19.21 & 28.24 & 19.15 \\
\hline
\end{tabular}

Keterangan: Angka-angka yang diikuti oleh huruf yang sama tidak berbeda nyata setelah dilakukan uji HSD Tukey dengan taraf kepercayaan 95\%, (-) : tidak ada interaksi.

Tabel 1 menyajikan data kadar lengas pada lingkungan tumbuh tanaman. Tabel tersebut menunjukkan tidak terjadi interaksi antara kultivar dengan pengukuran pada kadar lengas tanah. Pada 4 MST dan saat panen tidak terdapat perbedaan kadar lengas tanah baik sebelum maupun setelah penyiraman. Pada umur tanaman 8 minggu setelah tanam, kadar lengas pada lingkungan tumbuh Anjasmoro sebelum penyiraman berbeda nyata dengan kadar lengas pada lingkungan tumbuh Burangrang, Dering 1, dan Devon 1. Kadar lengas pada lingkungan tumbuh Demas 1 tidak menunjukkan perbedaan dengan kadar lengas kultivar lainnya. Sesudah penyiraman, kadar lengas tanah masing-masing kultivar tidak menunjukkan adanya perbedaan nyata. 
Sebelum disiram lengas tanah berada dalam kondisi rendah dan akan meningkat setelah penyiraman. Hasil pengujian kadar lengas tanah yang dilakukan penyiraman pada perlakuan kekeringan menunjukkan nilai yang lebih kecil dan berbeda nyata dibanding kadar lengas tanah pada perlakuan cukup air, namun belum mencapai kondisi titik layu permanen. Menurut Helmy dan Bakar (2017) besarnya titik layu permanen untuk komoditas kedelai pada tanah inceptisol adalah 3\%. Pada perlakuan cukup air, baik sebelum maupun setelah penyiraman, kadar lengas selalu mendekati kondisi kapasitas lapangan. Kapasitas lapangan adalah kondisi ketika kandungan air maksimum yang dapat ditahan oleh tanah setelah air pada kondisi jenuh turun ke bawah akibat gravitasi, umumnya 1 atau 2 hari setelah kondisi jenuh. Besarnya nilai kapasitas lapang menurut Oktaviani et al. (2013) adalah 39,1\%.

Lengas tanah merupakan faktor lingkungan yang berpengaruh terhadap pertumbuhan dan hasil tanaman budidaya. Menurut Lamina (1989) cit. Ichsan et al. (2010) kandungan air tanah yang baik untuk kedelai adalah pada saat kapasitas lapang. Pertumbuhan tanaman akan semakin baik dengan naiknya kelembaban tanah sampai batas tertentu. Menurut Budisantoso dan Hari (2001), tanaman kedelai yang mengalami cekaman air dapat terhambat pertumbuhannya. Cekaman air 75\% kapasitas lapang mengakibatkan pertumbuahn yang berbeda dengan cekaman air kapasitas lapang.

Dalam penelitian ini jumlah akar yang dihitung adalah seluruh akar sekunder yang menempel pada akar primer. Jumlah akar ini menentukan bagaimana percabangan akar bila dibandingkan antara akar tanaman yang diberi perlakuan kekeringan dengan akar tanaman pada perlakuan cukup air. Dari Tabel 2 dapat dilihat bahwa jumlah akar tidak selalu mengalami kenaikan seiring bertambahnya umur tanaman. Selain itu, jumlah akar tanaman tidak dipengaruhi oleh interaksi antara kultivar dengan pengairan. Pada saat tanaman berumur 4 MST dan 8 MST tidak terlihat adanya beda nyata antar jumlah akar kultivar, sedangkan pada saat panen kultivar Dering 1 menunjukkan jumlah akar lebih banyak dibanding dengan kultivar Anjasmoro, namun tidak berbeda dengan kultivar lainnya. Untuk faktor pengairan, pada saat tanaman berumur 4 MST perlakuan kekeringan belum menunjukkan pengaruh terhadap jumlah akar tanaman kedelai. Kondisi lingkungan tumbuh yang kering menurunkan jumlah akar pada tanaman kedelai terutama pada 8 MST dan saat panen. Pada umur tanaman 8 MST dan saat panen, perlakuan kekeringan menurunkan jumlah akar secara nyata. 
Tabel 2. Jumlah akar pada $4 \mathrm{mst}, 8 \mathrm{mst}$ dan panen

\begin{tabular}{|c|c|c|c|}
\hline \multirow{2}{*}{ Perlakuan } & \multicolumn{3}{|c|}{ Jumlah Akar } \\
\hline & $4 \mathrm{mst}^{*}$ & $8 \mathrm{mst}^{* *}$ & Panen \\
\hline \multicolumn{4}{|l|}{ Kultivar } \\
\hline Anjasmoro & $77.67 \mathrm{a}$ & $152.5 \mathrm{a}$ & 110.75 b \\
\hline Burangrang & $102.33 \mathrm{a}$ & $115.08 \mathrm{a}$ & $118.83 a b$ \\
\hline Demas 1 & $90.58 a$ & $144.75 \mathrm{a}$ & $136.33 \mathrm{ab}$ \\
\hline Dering 1 & $59.25 \mathrm{a}$ & $83.67 \mathrm{a}$ & $151.50 \mathrm{a}$ \\
\hline Devon 1 & $90.17 \mathrm{a}$ & $135.5 \mathrm{a}$ & $135.25 \mathrm{ab}$ \\
\hline \multicolumn{4}{|l|}{ Pengairan } \\
\hline Cukup Air & $93.5 \mathrm{a}$ & $159.8 \mathrm{a}$ & $198.79 a$ \\
\hline Kekeringan & $74.5 \mathrm{a}$ & $92.8 \mathrm{~b}$ & $64.70 \mathrm{~b}$ \\
\hline Interaksi & - & - & - \\
\hline CV (\%) & 10.15 & 17.53 & 15.07 \\
\hline \multicolumn{4}{|c|}{ 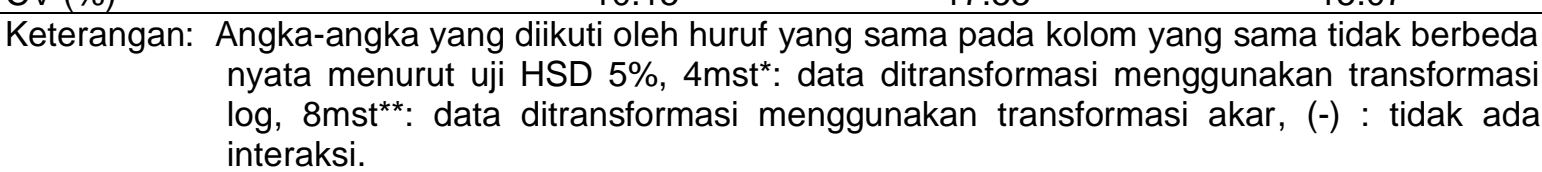 } \\
\hline
\end{tabular}

Menurut Waisel dan Eshel (2002) cit. Franco et al., (2011) percabangan akar yang menentukan jumlah akar biasanya akan menurun ketika ketersediaan air menurun. Berdasarkan teori tersebut, maka dapat dikatakan bahwa tanaman-tanaman tersebut tahan terhadap kekeringan. Ketersediaan air yang menurun selama proses pertumbuhan akan mengakibatkan pertumbuhan sel tanaman melambat pula, sehingga jumlah akar tanaman akan cenderung menurun dibandingkan ketika kondisi air terpenuhi.

Berat kering akar merupakan representatif asimilat yang ditimbun dalam akar. Asimilat yang ditimbun dalam akar tersebut menunjukkan besarnya hasil fotosintesis tanaman yang disalurkan pada akar.

Tabel 3 menunjukkan bahwa tidak ada interaksi antara faktor kultivar dan pengarian pada berat kering akar. Pada umur tanaman 4 minggu setelah tanam kultivar Burangrang menunjukkan berat kering akar yang nyata lebih besar dibanding kultivar Dering 1 1. Pada saat tanaman 8 MST berat kering akar tidak berbeda nyata antar kultivar. Pada saat panen, berat kering akar kultivar Demas 11 menunjukkan berat yang berbeda nyata dengan kultivar Dering 11 . Perlakuan kekeringan tidak mempengaruhi berat kering akar pada umur tanaman 4 MST. Pada saat tanaman 8 MST dan panen perlakuan kekeringan menurunkan berat kering akar secara nyata. Pada kondisi kekeringan berat kering akar cenderung lebih kecil dibandingkan saat kondisi air tercukupi. Menurut Ai dan Torey (2013) penurunan ketersediaan air tanah menurunkan berat kering tanaman, termasuk akar. Hal tersebut karena saat tanaman mengalami kekurangan air 
Purbowahyuani et al., / Vegetalika. 2019. 8(4):237-250

secara internal akan berakibat langsung pada penurunan pembelahan dan pembesaran sel.

Tabel 3. Berat kering akar pada $4 \mathrm{mst}, 8 \mathrm{mst}$ dan panen

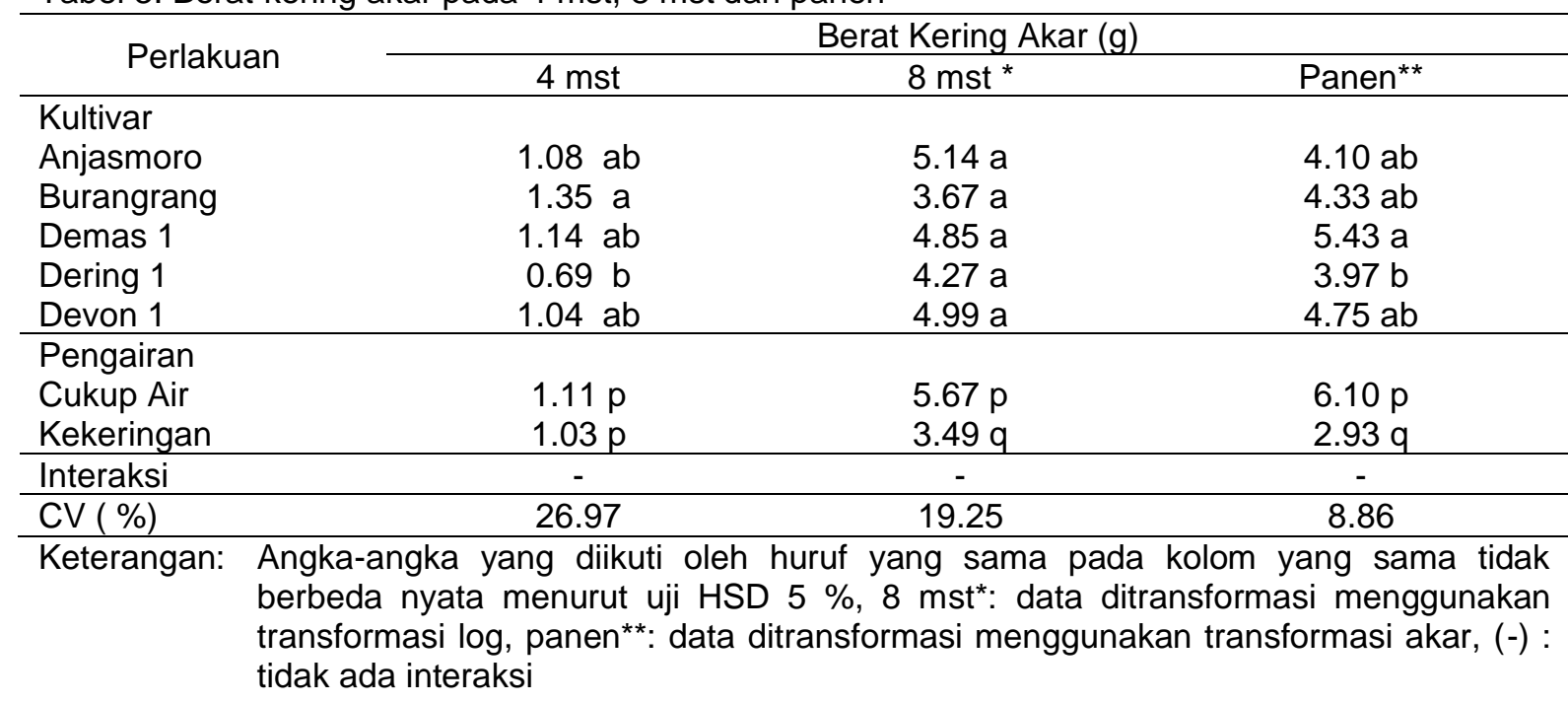

Perpanjangan akar merupakan hasil perpanjangan sel-sel akar di belakang meristem ujung. Panjang akar berkaitan erat dengan kemampuan penyerapan air oleh akar tanaman. Semakin panjang akar suatu tanaman maka diharapkan tanaman akan semakin baik dalam menyerap air dan unsur hara.

Tabel 4. Panjang akar total pada $4 \mathrm{mst}$

\begin{tabular}{|c|c|c|c|}
\hline \multirow{3}{*}{ Kultivar } & \multicolumn{3}{|c|}{ Panjang Akar Total (m) } \\
\hline & \multicolumn{2}{|c|}{$4 \mathrm{mst}^{\star}$} & \multirow{2}{*}{ Rerata } \\
\hline & Cukup Air & Kekeringan & \\
\hline Anjasmoro & $15.71 \mathrm{ab}$ & $16.75 a b$ & 16.23 \\
\hline Burangrang & $24.01 \mathrm{ab}$ & $18.13 a b$ & 21.07 \\
\hline Demas 1 & $23.38 a b$ & $15.48 a b$ & 19.43 \\
\hline Dering 1 & $12.07 \mathrm{~b}$ & $20.91 \mathrm{ab}$ & 16.49 \\
\hline Devon 1 & $37.67 \mathrm{a}$ & $16.23 a b$ & 26.95 \\
\hline Rerata & 22.568 & 17.5 & + \\
\hline CV & \multicolumn{3}{|c|}{11.32} \\
\hline trai & da interak & $\begin{array}{l}\text { ama pada } \\
: \text { data ditra }\end{array}$ & $\begin{array}{l}\text { sama tidak } \\
\text { nggunakan }\end{array}$ \\
\hline
\end{tabular}


Tabel 5. Panjang akar pada $8 \mathrm{mst}$

\begin{tabular}{|c|c|c|c|}
\hline \multirow{3}{*}{ Kultivar } & \multicolumn{3}{|c|}{ Panjang Akar Total (m) } \\
\hline & \multicolumn{2}{|c|}{$8 \mathrm{mst}^{*}$} & \multirow{2}{*}{ Rerata } \\
\hline & Cukup Air & Kekeringan & \\
\hline Anjasmoro & $45.34 \mathrm{ab}$ & $16.04 \mathrm{~cd}$ & 30.69 \\
\hline Burangrang & $55.62 \mathrm{a}$ & $17.98 \mathrm{~cd}$ & 36.80 \\
\hline Demas 1 & $54.85 \mathrm{a}$ & $27.42 \mathrm{bc}$ & 41.14 \\
\hline Dering 1 & $53.43 \mathrm{a}$ & $11.29 \mathrm{~d}$ & 32.36 \\
\hline Devon 1 & $73.28 \mathrm{a}$ & $21.03 \mathrm{~cd}$ & 47.16 \\
\hline Rerata & 56.5 & 18.75 & + \\
\hline CV (\%) & & 5.36 & \\
\hline
\end{tabular}

Tabel 4 dan 5 menunjukkan bahwa ada interaksi antara kultivar dan pengairan pada panjang akar total. Pada 4 MST Panjang akar total pada kondisi cukup air menunjukan bahwa kultivar Devon 1 memiliki akar paling panjang dan berbeda nyata dengan Dering 1, namun tidak berbeda nyata dengan kultivar lainnya. Pada kondisi kekeringan, panjang akar total tanaman tidak menunjukkan adanya beda nyata pada masing-masing kultivar. Pada kondisi cukup air, panjang akar total pada masing-masing kultivar tidak menunjukkan beda nyata. Akan tetapi, pada kondisi kekeringan kultivar Demas 1 menunjukkan akar yang lebih panjang dibanding kultivar Dering 1. Terdapat kecenderungan bahwa pada kultivar yang memiliki akar lebih panjang pada kondisi cukup air akan mengalami penurunan panjang akar lebih besar saat kekeringan dibanding kultivar lain.

Tabel 6 menunjukkan bahwa tidak ada interaksi antara kultivar dan pengairan pada panjang akar total saat panen. Kultivar Burangrang menunjukkan akar yang nyata lebih panjang dibanding dengan kultivar Dering 1. Perlakuan kekeringan menurunkan panjang akar hingga 50\% dibanding perlakuan cukup air.

Luas permukaan akar berhubungan dengan luas bidang kontak akar dengan partikel-partikel tanah. Jumlah hara yang dapat diserap oleh tanaman melalui intersepsi akar bergantung dari jumlah kontak antara akar dengan hara tersebut. Semakin banyak rambut akar, maka akan semakin tinggi luas permukaan akar yang akan kontak langsung dengan hara dalam tanah. kar juga berhubungan dengan kemampuan unutk mengabsorbsi air dan hara. 
Purbowahyuani et al., / Vegetalika. 2019. 8(4):237-250

Tabel 6. Panjang akar pada saat panen

\begin{tabular}{|c|c|}
\hline \multirow{2}{*}{ Perlakuan } & \multirow{2}{*}{$\frac{\text { Panjang Akar Total }(\mathrm{m})}{\text { Panen }}$} \\
\hline & \\
\hline Kultivar & \\
\hline Anjasmoro & $48.99 a b$ \\
\hline Burangrang & $55.61 \mathrm{a}$ \\
\hline Demas 1 & $47.03 \mathrm{ab}$ \\
\hline Dering 1 & $37.77 b$ \\
\hline Devon 1 & $48.19 \mathrm{ab}$ \\
\hline Pengairan & \\
\hline Cukup Air & $62.57 p$ \\
\hline Kekeringan & $32.55 \mathrm{q}$ \\
\hline Interaksi & - \\
\hline CV (\%) & 16.2 \\
\hline
\end{tabular}

Luas permukaan akar pada Tabel 7 menunjukkan tidak ada interaksi antara kultivar dengan pengairan pada semua umur tanaman. Pada umur 8 minggu setelah tanam tidak menunjukkan ada beda nyata antar luas permukaan akar kultivar, namun pada umur 4 minggu setelah tanam dan saat panen ada beda nyata. Kultivar Burangrang menunjukkan akar yang lebih luas dibanding kultivar Dering 1. Pada saat panen kultivar Demas 1 nyata lebih luas dibanding kultivar Anjasmoro. Kekeringan sudah menurunkan luas permukaan secara signifikan pada umur tanaman 4 minggu dan saat panen, namun pada umur 8 minggu kekeringan justru tidak memberikan pengaruh penurunan luas permukaan akar yang signifikan dibandingkan dengan kondisi cukup air.

Diameter akar dapat memberikan informasi penting dalam hubungannya dengan ukuran pori tanah dan potensial penetrasi akar. Ukuran diameter akar akan mempengaruhi kemampuan akar dalam upaya menyerap air bagi tanaman. 
Tabel 7. Luas permukaan akar pada $4 \mathrm{mst}, 8 \mathrm{mst}$ dan panen

\begin{tabular}{|c|c|c|c|c|}
\hline \multirow{2}{*}{\multicolumn{2}{|c|}{ Perlakuan }} & \multicolumn{3}{|c|}{ Luas Permukaan Akar $\left(\mathrm{m}^{2}\right)$} \\
\hline & & $4 \mathrm{mst}$ & 8 mst $^{\star}$ & Panen** $^{\star *}$ \\
\hline \multicolumn{5}{|l|}{ Kultivar } \\
\hline Anjasmoro & & $1.64 a b$ & $3.53 \mathrm{a}$ & $2.14 \mathrm{~b}$ \\
\hline Burangrang & & $1.86 \mathrm{a}$ & $2.91 \mathrm{a}$ & $3.02 \mathrm{ab}$ \\
\hline Demas 1 & & $1.74 \mathrm{a}$ & $3.21 \mathrm{a}$ & $6.13 \mathrm{a}$ \\
\hline Dering 1 & & $1.08 \mathrm{~b}$ & $3.06 \mathrm{a}$ & $2.55 \mathrm{~b}$ \\
\hline Devon 1 & & $1.66 \mathrm{a}$ & $3.52 \mathrm{a}$ & $5.6 a b$ \\
\hline \multicolumn{5}{|l|}{ Pengairan } \\
\hline Cukup Air & & $1.72 p$ & $3.76 p$ & $6.70 p$ \\
\hline Kekeringan & & $1.47 \mathrm{q}$ & $2.74 p$ & $2.85 \mathrm{q}$ \\
\hline Interaksi & & - & - & - \\
\hline CV ( \%) & & 22.83 & 29.02 & 13.26 \\
\hline Keterangan: & $\begin{array}{l}\text { Ang } \\
\text { ber } \\
\text { tran } \\
\text { tida }\end{array}$ & $\begin{array}{l}\text { diikuti ol } \\
\text { nurut uji } 1 \\
\text { anen**: da }\end{array}$ & $\begin{array}{l}\text { sama } \\
\text { st*: da } \\
\text { asi men }\end{array}$ & $\begin{array}{l}\text { yang sama tidak } \\
\text { asi menggunakan } \\
\text { sformasi log (-): }\end{array}$ \\
\hline
\end{tabular}

Tabel 8. Diameter akar pada $4 \mathrm{mst}, 8 \mathrm{mst}$ dan panen

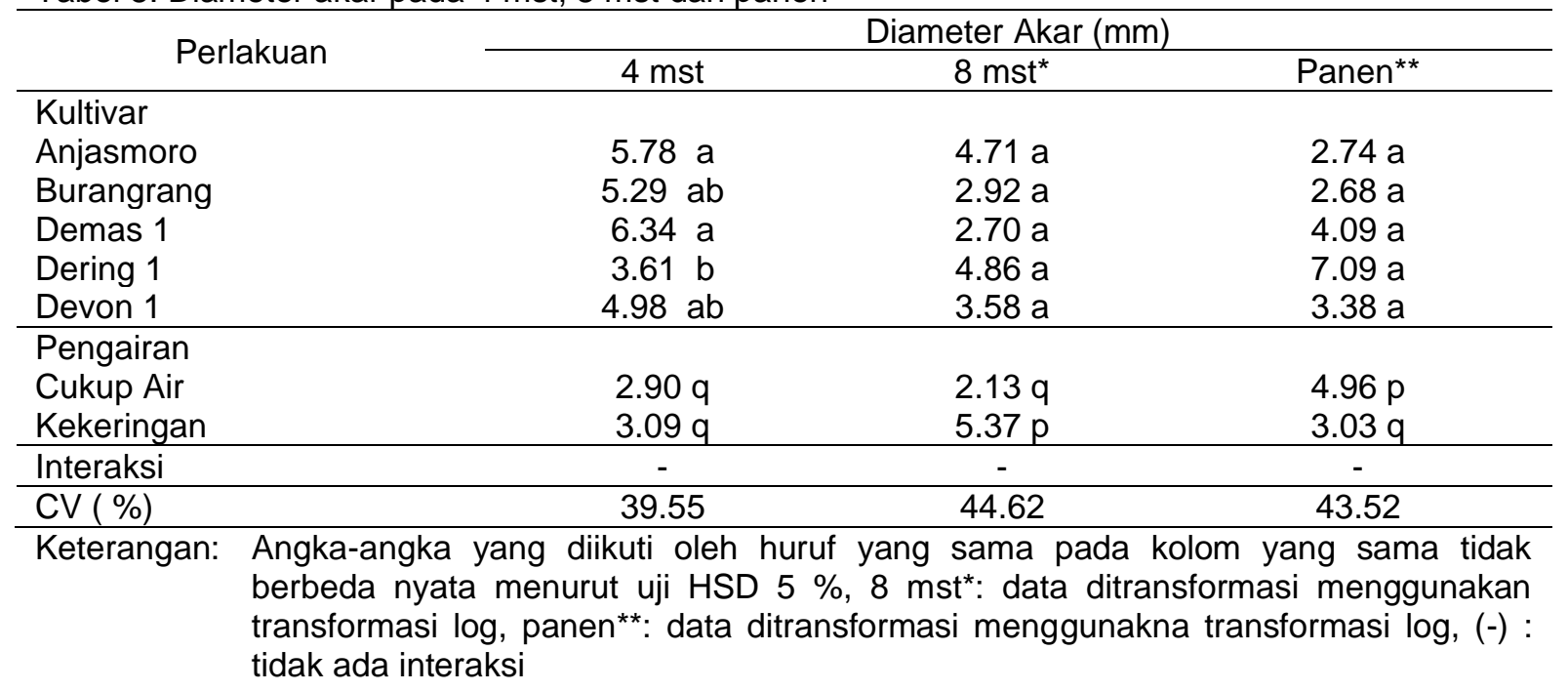

Dari Tabel 8 terlihat bahwa tidak ada interaksi antara kultivar dengan pengairan pada diameter akar tanaman di semua umur tanaman. Pada umur tanaman 4 minggu kultivar Demas 1 dan Anjasmoro menunjukkan diameter akar yang berbeda nyata dengan kultivar Dering 1. Pada umur tanaman 8 minggu dan panen diameter akar masing-masing kultivar tidak menunjukkan perbedaan yang nyata. Pada faktor pengairan saat berumur terhadap tanaman 4 minggu kondisi kekeringan belum memberikan pengaruh yang signifikan diameter akar tanaman. Pada umur 8 minggu perlakuan kekeringan meningkatkan ukuran diameter akar dibandingkan pada kondisi cukup air. Pada saat 
panen, perlakuan kekeringan mempengaruhi diameter akar yang lebih kecil dan berbeda nyata dibanding diameter pada kondisi cukup air.

Tanaman dalam kondisi kekeringan memodifikasi bagian tubuhnya terutama perakaran agar tetap bertahan meskipun kekurangan air. Kekurangan air secara internal pada tanaman berakibat langsung pada penurunan pembelahan dan pebersaran sel. Pada tahap pertumbuahn vegetatif, air digunakan oleh tanaman untuk pembelahan dan pembesaran sel yang terwujud dalam pertambahan tinggi tanaman, pembesaran diameter dan pertumbuhan akar, termasuk diantaranya adalah pemanjangan akar (Subantoro, 2014). Panjang akar merupakan indikator kemampuan tanaman untuk menyerap air dari lapisan tanah yang lebih dalam, dan dipengaruhi oleh penetrabilitas akar (Franco et al., 2011).

Luas permukaan akar pada tanaman Silene vulgaris mengalami peningkatan ketika berada dalam kondisi tercekam kekeringan sedang (Franco et al., 2008 cit. Franco, 2011). Hal ini dapat meminimalisir penipisan air tanah di sekitar akar, sehingga akan meminimalisir daya tahan untuk mengangkut air menuju ke sistem perakaran. Selain itu, semakin sedikit jumlah air tersedia, semakin rendah kadar air pada tanah maka kelembaban sekitar perakaran akan menurun sehingga dapat menghambat perpanjangan, kedalaman penetrasi serta ukuran diameter akar (Wiyono, 2009).

Indeks Toleransi Cekaman (ITC) kekeringan mencerminkan tingkat toleransi tanaman kedelai terhadap cekaman kekeringan.Semakin tinggi nilai ITC suatu tanaman, maka tanaman tersebut semakin toleran terhadap cekaman (Fernandez, 1992 cit. Efendi dan Azrai, 2015).

Indeks Toleransi Cekaman (ITC) kekeringan mencerminkan tingkat toleransi tanaman kedelai terhadap cekaman kekeringan. Semakin tinggi nilai ITC suatu tanaman, maka tanaman tersebut semakin toleran terhadap cekaman. Tingkat toleransi ditentukan dari nilai ITC yang berkisar antara 0-1 dan dikelompokkan menjadi 5 kelas toleransi, yaitu peka $(0-0,2)$, agak peka $(0,2<x<0,4)$, moderat $(0,4<x<0,6)$, agak toleran $(0,6<x<0,8)$, dan toleran $(0,8<x<1,0)$ (Fernandez, 1992 cit. Nurmalasari et al., 2015). 
Tabel 9. Nilai indeks toleransi cekaman (ITC) berat kering total tanaman

Kultivar

Anjasmoro

Burangrang

Demas 1

Dering 1

Devon 1
ITC Berat Kering Total Tanaman

$0.379 \mathrm{ab}$

$0.842 \mathrm{a}$

$0.455 \mathrm{ab}$

$0.461 \mathrm{ab}$

Keterangan: Angka-angka yang diikuti oleh huruf yang sama pada kolom yang sama tidak berbeda nyata menurut uji Duncan $5 \%$.

Berdasarkan Tabel 9 kultivar Demas 1 menunjukkan nilai ITC paling tinggi yaitu 0,842 dan termasuk ke dalam kriteria toleran, sedangkan Dering 1 dan Devon 1 termasuk kriteria moderat. Kultivar Anjasmoro dan Burangrang dengan nilai ITC Berat Kering 0,297 dan 0,379 berdasarkan Tabel 8 menunjukkan kriteria agak peka.

Peningkatan brangkasan kering pada saat kekeringan disebabkan oleh terbatasnya pasokan air dan nutrient untuk tunas. Tingkat toleransi tanaman kedelai terhadap cekaman naungan ditentukan oleh besarnya tingkat penurunan produksi akibat cekaman kekeringan. ITC merupakan index yang terbaik untuk mengidentifiasi tanaman yang berada pada kondisi tercekam maupun non tercekam (Purdad, 2008 cit. Kargar et al., 2014).

Tabel 10. Korelasi antara sifat perakaran dan itc berat kering

\begin{tabular}{lcccccccc}
\hline & BS & BK & $\begin{array}{c}\text { Jumlah } \\
\text { Akar }\end{array}$ & Volume & $\begin{array}{c}\text { Panjang } \\
\text { Akar }\end{array}$ & $\begin{array}{c}\text { Diameter } \\
\text { Akar }\end{array}$ & $\begin{array}{c}\text { Luas } \\
\text { Permukaan }\end{array}$ & $\begin{array}{c}\text { ITC } \\
\text { BK }\end{array}$ \\
\hline BS & 1 & & & & & & & \\
BK & $0.94^{*}$ & 1 & & & & & \\
$\begin{array}{l}\text { Jumlah Akar } \\
\text { Volume }\end{array}$ & $0.99^{*}$ & $0.93^{*}$ & 0.86 & $0.93^{*}$ & 1 & & & \\
$\begin{array}{l}\text { Panjang } \\
\text { Akar }\end{array}$ & 0.45 & 0.33 & 0.38 & 0.03 & 1 & & \\
Diameter & & & & & & \\
Akar & -0.7 & -0.45 & -0.75 & -0.72 & -0.29 & 1 & \\
Luas & 0.51 & 0.6 & 0.45 & 0.57 & -0.14 & -0.02 & 1 & \\
$\begin{array}{l}\text { Permukaan } \\
\text { ITC BK }\end{array}$ & 0.59 & 0.62 & 0.5 & 0.54 & 0.12 & -0.11 & $0.96^{*}$ & 1 \\
\hline
\end{tabular}

Keterangan: Angka yang ditampilkan merupakan koefisien korelasi dari uji korelasi. ${ }^{*}=$ menunjukkan nilai koefisien korelasi siginifikan pada uji korelasi $(\alpha=0.05)$. BS $=$ Berat Segar, $B K=$ Berat Kering

Tabel 10 menunjukkan bahwa Indeks Toleransi Cekaman (ITC) berat kering tanaman berkorelasi nyata dengan luas permukaan akar. Melalui peningkatan luas 
permukaan akar, tanaman akan memperluas daya serap air untuk pertumbuhan. Oleh karena itu toleransi tanaman terhadap kekeringan akan meningkat seiring dengan peningkatan luas permukaan akar. Tanaman yang mempunyai toleransi terhadap kekeringan tinggi, sewajarnya akan tumbuh lebih tinggi dibanding tanaman yang toleransinya terhadap kekeringan rendah. Mekanisme untuk meningkatkan penyerapan air adalah melalui perluasan permukaan akar sebagai bentuk water uptake. Semakin luas permukaan akar, maka bidang kontak akar dengan tanah sebagai upaya penyerapan air akan semakin besar (Brunner et al., 2015).

\section{KESIMPULAN}

Berdasarkan penelitian yang telah dilakukan diperoleh kesimpulan bahwa kultivar kedelai yang tahan kekeringan memiliki permukaan akar yang lebih luas dibanding kultivar kedelai yang rentan kekeringan. Diantara kultivar yang diuji, kultivar kedelai yang paling tahan terhadap kekeringan adalah Demas 1.

\section{DAFTAR PUSTAKA}

Ai, N.S. dan P. Torey. 2013. Karakter morfologi akar sebagai indicator kekurangan air pada tanaman. 32 Jurnal Bioslogos. 3(1): 31-39.

Badan Litbang Pertanian. 2012. Pengembangan Kedelai di Kawasan Hutan Sebagai Sumber Benih.Agroinovasi, Jawa Tengah. Hal. 2.

Brunner, I., C. Herzog, M. A. Dawes, M. Arend, and C. Sperisen. 2015. How tree roots respond to drough. Front Plant Sci. 6:547-563.

Efendi, R. dan M. Azrai. 2015. Kriteria indeks toleran jagung terhadap cekaman kekeringan dan nitrogen rendah. Prosiding Seminar Nasional Serealia. Balai Penelitian Tanaman Serealia, Sulawesi Selatan.

Fernandez, G.C.J., 1992. Effective selection criteria for assessing plant stress tolerance. Proceedings of the International Symposium on Adaptation of Vegetables and other Food Crops in Temperature and Water Stress, August 13-16, 1992, Shanhua, Taiwan, pp: 257-270.

Franco, J. A. 2011. Root development under drought stress. Technology and Knowledge Transfer e-Bulletin. 2(6): 1-3

Helmy, S. dan B. A. Bakar. 2017. Teknologi Pengendalian Cekaman Air pada Komoditi Padi dan Kedelai. <http://nad.litbang.pertanian.go.id/ind/index.php/infoteknologi/696-teknologi-pengendalian-cekaman-air-pada-komoditi-padi-dankedelai>. Diakses pada 26 Desember 2017. 
Ichsan, C. N., M. Hayati, dan S. P. Mashtura. 2010. Respon kedelai kultivar kipas putih dan wilis pada kadar air tanah yang berbeda terhadap pertumbuhan dan hasil. Agrista. 14(1): 25-29.

Kargar, S. M. A., A. Mostafaie, E. M. Hervan, and S. S. Pourdad. 2014. Evaluation of soybean genotypes using drought stress tolerant indices. International Journal of Agronom and Agriculturan Research (IJAAR). 5(2): 103-113

Kasno, A. dan M. Yusuf. 1995. Evaluasi plasma nutfah kedelai untuk daya adaptasi terhadap kekeringan. Jurnal Ilmu Pertanian Indonesia. 4(1): 12-15.

Kunert, K. J., B. J. Vorster, B. A. Fenta, T. Kibido, G. Dionisio, and C. H. Foyer. 2016. Drought stress responses in soybean roots and nodules. Front Plant Science. 7:1015.

Licht, M.A., D. Wright, dan A. W. Lenssen. 2013. Soybean response to drought. Agriculture and Environtment Extension Publication. 190.

Mederski, H.J., D.L. Jeffers, and D.B. Peters. 1973. Water and Water Relation. InSoybean Improvement Production and Uses. Agronomy Series 16. Am. Soc. Agro.

Nurmalasari, I. R., E. Purwanto, dan Pardono. 2015. Kajian terhadap cekaman air pada padi hitam dan padi merah. El-Vivo. 3(1): 25-33

Oktaviani, S. Triyono, dan N. Haryono. 2013. Analisis neraca air budidaya tanaman kedelai (Glycine max (L.) Merr) pada lahan kering. Jurnal Teknik Pertanian Lampung. 2(1): 7-16.

Subantoro, R. 2014. Pengaruh cekaman kekeringan terhadap respon fisiologis perkecambahan benih kacang tanah (Arachis hypogaea L.). Mediagro. 10(2): 32-44

Wiyono. 2009. Respon beberapa varietas kedelai (Glycine max L. Merr) terhadap cekaman air. Agrineca. 3(03): 1-11. 